\title{
A few remarks on the (im)perfection of the term securities: a theoretical study
}

\author{
Associate professor Tomáš PERÁČEK ${ }^{1}$
}

\begin{abstract}
This theoretical study is primarily anchored in the area of economic theory, legal theory and law. It seeks a multidisciplinary and comparative examination of issues, the concept and regulation of which remains largely unfinished in the international economic, legal environment and in the decades of professional and laconic debates. Not only in economic terms, there are numbers of unanswered questions in the long term, not only in economic practice. However, as the concept of a security is a matter of non-economic interest as well as legal theorists, the answers to the lack of clarity and difficulties are quite difficult to find. The aim of the study is to contribute to the correct economic and theoretical definition of a key concept in the field of securities. The setting of this objective is based directly on needs and emerging practical problems in business practice. Indeed, their proper understanding and application has a fundamental impact on the contractual trading of securities in global terms. In connection with the processing of the matter, we have applied primarily qualitative methods, having regard to the nature of the subject of the matter under examination (methodological and economic terms). However, we also make use of scientific literature, case-law and the analogy of law, providing our contribution with qualifying responses to the pitfalls of economic and legal practices.
\end{abstract}

Keywords: economic theory; law order, legal theory; securities.

JEL Classification: K10, K22, M21

DOI: $10.24818 / \mathrm{TBJ} / 2021 / 11 / 2.01$

\section{Introduction}

Securities and trade are one of the essential characteristics of the economic sovereignty of each state. They represent a very effective way of allocating the available funds, with the consequent position on deficit units, which can use them more efficiently. However, such a possibility to transfer capital is strictly regulated by its legal order, but primarily by the Securities and Investment Services Act.

As with other terms, it is also possible, in the case of a security, to discuss different concepts of that term. This is particularly the case in the field of economics and law. It is therefore possible to refer to the economic and legal concept of a security. However, while the economics exists only as a single discipline, it is precisely what is known as a scientific discipline that can be raised in a sense that is a dual sense. On the one hand, a discipline which deals, inter alia, with securities,

1 Tomáš Peráček - Comenius University in Bratislava, Faculty of Management, Slovakia, tomas.peracek@fm.uniba.sk. 
including the law as such the body of rules on which the securities are to be subject. From the three sources, knowledge is needed about what the security is. We will therefore examine the term 'security' from the point of view of economic theory, legal theory and, finally, the law of several states.

The issue of securities is faced with a general lack of interest, which, in our view, may result not only in economists but, in particular, lawyers, but, despite its undoubted importance in commercial practice, to examine this issue. The term 'security' is being examined by number of experts, in particular in the area of economic theory. However, this issue is a legal issue and it is the legislation of each State which determines the rules. For this reason, this article also seeks to contribute to a comprehensive view of the security. Our aim is also consistent with the structure of the article which, apart from the general sections, is divided into three main headings. Each of them comprehensively and critically examines a selected view of a security.

\section{The aim and methodology}

The main objective of the study is to provide a theoretical, logicalmethodological proposal for a more comprehensive and precise definition of the concept of a security in the economy and law. In addition to the main objective, we have chosen sub-objectives:

- to verify the presumption that, at present, the Slovak legislation is the most appropriate,

- analyze the notion of security in terms of economic theory, law theory and current legislation of selected states,

- critically assess and compare individual views on securities and possibly provide proposals "de lege ferenda".

In the connection with the processing of the matter, we have applied primarily qualitative methods, having regard to the nature of the subject of the matter under examination (methodological and economic terms). Our main objective and milestones are to be achieved, in particular thorough study of legislation and scientific literature, and case law. Due to the nature of the scientific study, a number of scientific methods are used to understand economics and law. This concerns the use of critical analysis for the review of the legal situation and of the legislation as well as in the abstract. Applying the comparative method is shared by the different views of economists and lawyers on the correctness of individual cards for securities. In doing so, we are seeking a multidisciplinarity. In the light of their own years of practical experience in the field of business law, we are also using the doctrinal interpretation. The relevant national laws are the necessary source of knowledge for the achievement of the main objective. These are, according to us, an appropriate and useful complement to the case law not only to the European but also the AngloAmerican courts having the aim of giving its view on the issues at issue. However, a specific, but not a less prominent place, is the scientific and scientific literature that we look at in our research. 


\section{Literature review}

In the most general sense, a security is a document embodying some of the rights of the proprietor against the issuer of that document. This generalization was made according to Van de Mierop ${ }^{2}$ for a long historical period, starting with the period of panisation of Alexander the Great in the $4^{\text {th }}$ century ago, with some of the authors saying even about the place of the abyssal empire. At the time, there were already first documents similar to the securities, by which the debtors confirmed their commitment to the creditors. During the period of Roman Empire, insufficient attention was given to the legal economic institution's legal economic institute and the classical Roman law was rather degraded and damaged. This was also the case, even though the ancient Rome had developed cash trade, in particular by bankers, who created the chain of asigration due to the savings of the final payments. However, there appeared to be a problem. The obligation to pay persons initially unappointed, within the meaning of today's clause, to the holder of the instrument not mentioned in the document (the bearer clause) could not be made in the money trade, since it directly contradicted the fundamental view of the Roman bond law ${ }^{3}$. Šlahor ${ }^{4}$ it is convinced that the creation of securities was therefore purely economic and it should have played the most important function of a swift and secure transfer of money and other assets, where at that time it was the biggest and the shortage and the need for business development.

Thus, from an economic point of view, a security is a particular asset which, through its operation on the financial market, allows the conversion of the money into equity. A security is a financial asset and is an important instrument for the realization of financial investments in the economy and the reason for its creation is therefore purely economic. This view is shared by the Macíková et al. "and adds that the security is an owner's record or claim against the issuer of the security". 5 The securities are then, according to Chovancová et al. "the associated property and other rights of the authorized person defined and laid down by the Securities Act. ${ }^{6}$ " The securities may, in its view, be held in two forms, either in paper form or bookentry form. In addition Lyocsa and Todorova "sees a credit facility to guarantee the debtor's ability to pay its obligation by exposing or transferring to a creditor, for example, a promissory note. " In such a case, the initial contractual relationship is cancelled, which is replaced by the relationship of the promissory note, provided that the creditor consents to such proceedings. Srebalová et al. "also refers to the payment function of the security because it can also be paid". ${ }^{8}$ The law allows the creditor and the debtor to agree that the settlement of the value of the security in the

\footnotetext{
${ }^{2}$ Van de Mierop, Dejiny, 125.

${ }^{3}$ Mucha, Tools, 573-580.

4 Šlahor, Vat, 1555-60.

${ }^{5}$ Macíková et al., Financial, 2274.

${ }^{6}$ Chovancová et al., Two, 2019.

${ }^{7}$ Lyocsa and Todorova, Trading, 628-45.

${ }^{8}$ Srebalová et al., Legal, 3385-94.
} 
future will be satisfied by the creditor's claim, for example, from the loan agreement. The security function of the security is, according to Simunova et al. "the provision of a security to the creditor that the debtor will be repaid by the debtor. It follows that they also have a hedging nature, often used as a means of securing credit. ${ }^{9}$ ",

One of the oldest springs Randa "is unusual and is very archaic for today's ratios and their existence is attached to a particular document. ${ }^{10}$ " According to the applicant, the first legal definition of that concept was already included in the German Commercial Code in 1863. Since then, legal theory is based on that definition. However, today number of theorists are already considered to be the most important sign of the material substrate - the document on which the express will of the intention is captured and will normally be an instrument. The Census of the Charter is the second character of the security, but it is only understood in the legal sense of the instrument ${ }^{11}$. As an advocate of the creative theory of the creation of a security, the legal theoretic Kotásek et al. argues that "the rights and obligations of a security arise from the time of its issue, that is to say, by writing a deed as a unilateral legal act without the need for acceptance. ${ }^{12}$ " Nor does Mucha "define the term 'security'. It states that the rights and obligations of the security are based on a security contract between the issuer and the first acquirer. ${ }^{13}$ " This theory also corresponds to the fact that legal relationships in the field of private law are essentially based on a concurrence of wills on the part of the parties. However, the question arises as to whether a security is issued even if its owner is in good faith but without a contract with the issuer.

\section{Economic view of the notion of security}

Even though it completely ignores science, it is necessary to look for the concept of a security in economic theory. The precious paper is, in fact, an economic category. It is a security paper that is mainly driven by economic needs, as well as economic functions. Furthermore, it forms an important subject of economic relations and is involved in their development. ${ }^{14}$ Nevertheless, it is not possible to speak of a common approach to economic theory. However, it is interesting to note that many economists leave, in their works dealing with securities, the very concept of 'totally unnoticed. However, this may not turn away where work is oriented towards other topics. The fact that the discussion of the securities is also lacking in works, which should be given sufficient attention to them, is striking. We also face this problem in a series of current economic works. ${ }^{15}$ The main scientific research stream focuses solely on the analysis of the role of securities in the process of supply

\footnotetext{
${ }^{9}$ Simonova et al., Financial, 69-80.

${ }^{10}$ Randa, O cennich, 15.

${ }^{11}$ Lalik, Slovak, 467-73.

12 Kotásek et al., Pravo, 227.

${ }^{13}$ Mucha, Výkon, 65.

${ }^{14}$ Svarc, Velka, 97.

${ }^{15}$ Gernat et al., What drives, 101095.
} 
and demand for financial capital, in particular in the context of the advantage of an investment in a security or its use to acquire capital as compared to other financial instruments. To this end, it is also closely linked to exploration in other areas, such as the theory of the securities portfolio. This science - a research course - is entirely natural, but at all does not give an idea of the concept of a security. In addition, it is characterized by a restriction only for selected types of securities most frequently used, such as shares and bonds, whereas other securities will not reach their attention.

Samuelson and Nordhaus "do not define as a wide range of monetary assets, such as shares, bonds, options, treasury bills, documents certifying the ownership of those assets. ${ }^{16}$ " However, this work suffers from a significant imperfection of the security in the definition of security. For the definition of a security, a non-exhaustive list of valuable papers is indeed insufficient, which gives us the need to object to it. Treasury bills, for example, are nothing other than one of the types of obligation. Here too, the question arises as to whether it is possible to refer only to monetary assets for securities.

A foreign author other than Mishkin "provides a definition in accordance with which securities are referred to as financial instruments - claims of future income or total assets of the borrowing facility, with liabilities for this person, while for their acquirers they are assets. ${ }^{17}$ "In foreign encyclopedic literature, we are confronted with a dual perspective on securities. In the strict sense, they are characterized as exchange traded paper or secondary capital markets. In the broad sense, they are then defined according to Bannock et al. "as documents giving title to ownership or entitlement to income, which may be composed as a seizure for a bank loan. ${ }^{18}$, Penant - Rea treats them in the broad sense as documents conferring the ownership of property or the right to receive income which may serve as a guarantee for a bank credit in the future. ${ }^{19}$

The Slovak economic literature notes that economically valuable paper is a "particular asset value that allows money to be converted into equity through its functioning on the financial market. A security is a financial asset and is an important tool for realizing financial investments in the economy. ${ }^{20}$ ",

However, foreign economics such as Fuchs and Tulejaseek "to close this gap and define a security. This is merely an apparent attempt. However, in terms of the result, it is not a successful attempt, since the authors merely state that the securities provide, first and foremost, the property rights of their ownership. ${ }^{21}$," However, such a finding is not a definition but a definition of a security. A less critical assessment merits the view of the Czechoslovak post-war economy, Engliš, "which stressed that a security is a form of capital that enables the debtor to be

\footnotetext{
${ }^{16}$ Samuelson and Nordhaus, The Econimics, 74.

${ }^{17}$ Mishkin, The Economics of, 125.

${ }^{18}$ Bannock and Baxter, The penguin, 45.

${ }^{19}$ Penant - Rea and Emmont, The Pocket, 174.

${ }^{20}$ Bohdalová and Greguš, Stochastic, 184.

${ }^{21}$ Fuchs and Tuleja (2005).
} 
mobilized and the debtor at any time in force. ${ }^{22}$ ", It also concluded that the securities are those that serve the portability and mobilization of capital and the increased willingness to borrow money, followed by the definition of individual types of securities, such as bonds, bonds, pledges. ${ }^{23} \mathrm{We}$ can see a valuable paper at all. On the other hand, there is also considerable uncertainty as to the uncertainty of the defined term, since it is not possible to define the concept of a security and even less fully to define its functions at all.

Bartošek seeks "to establish a multidisciplinary security for the security, consisting of its economic definition, which is indissociable from a legal theoretical

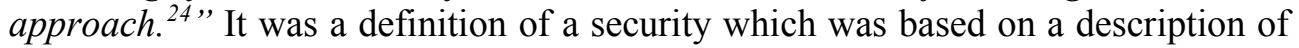
the development of the transferability of the debt, with the subsequent admission of their transferability in the form of a concession, first, according to the author, that a security was created in the sense of the instrument of proof and later on the creation of a perfect security. From that structure, the author inferred the concept of the security as the legal instrument, which is the holder of the claim, which it transfers with him, and it stands and falls. In our view, such a concept has the character of a correct definition of the concept of a security subject to a restrictive definition. The problem can be seen in the fact that the security is linked only to the claim to which it is a subject. We do not question the fact that, for the most part, in the economic practice, the security is a security holder, but in the case of an action it guarantees both the shareholder and the company to manage the company. Blackwell is a wellestablished stereotype of economic theory. ${ }^{25}$ In a relatively interesting way, a security is defined as a specific subject of a private law relationship, the essence of which is an incorporation of rights with a written declaration of intent in the cases provided for by law. In this case, the merger with the theoretical legal concept of a security is almost complete as it blurs most of the differences between economic and legal theories. It is also probably the fact that the author of that definition has been an original qualification by a legal professional.

\section{Legal - theoretical view of a security}

The legal theory of the sources of knowledge of the concept of a security is different from the economic, but not entirely without exception. This is confirmed by number of clarifications which the concept of a security requires. Neither is the designation 'legal basis for the theoretical concept of a security' in its entirety, which is due to the fact that it is also found in the economic literature on which it is based in part. However, if we are talking about the legal theory concept of a security, it cannot be understood to mean something which would have been, although generally accepted in only one form only in legal literature and in legal practice. In fact, the definition of a security is number of legal commentators, which, despite their

\footnotetext{
22 Englis, Národní, 120.

${ }^{23}$ Mura et al., Quantitative, 212-24.

${ }^{24}$ Bartošek, Encyklopedia, 220.

${ }^{25}$ Blackwell et al. Modern, 745.
} 
similarities, are very often different. This is mainly due to the different historical developments of individual states, as inconsistencies have been shown already in the maturing periods of the securities.

According to Korauš et al. ${ }^{26}$ to define that term, Czech legal theory focused on the German legal theory of Brunner. The former systematically summarized the various forms of securities used in commercial practice into the single category and separated them from other instruments of legal relevance. As a result of its activity, the first definition of a security was formulated in 1882, according to which 'the security is a private law instrument the application of which is governed by private law control' and that its position in German law continues to exist today. As referred to in Chance and Brooks, "the commercial law and the securities right 'constitute an instrument in which private law is guaranteed in writing in such a way that the possession of a document is necessary in writing. ${ }^{27}$ " However, such traditional definitions of the security could not be applied to book-entry securities in which the written form is replaced by an entry in a certain register. However, the deed and the entry in a certain register are by their nature a sort of boxing and therefore Kotásek et al. ${ }^{28}$ "as the most appropriate definition which can be applied to both the documentary and dematerialized securities, the legal opinion of Dédič and Pauly ${ }^{29}$ was considered to be the most appropriate." According to them, 'a valuable paper is a written act of intent (descriptive act), with which a subjective right is attached in such a way that the disposition of that right is possible only at the same time as the disposition of the box act.' That view was shared by the Bratislava Regional Court in its judgment on the amendment of the order for payment. ${ }^{30}$ According to him, the bill of exchange is a perfect security or a perfect security, so called a box. This means that the rights and obligations of changing relationships are defined by the law only, and only with an amending instrument, the alerts on it, and can only exist together with this instrument.

Despite the unequal diversity of opinions on the concept of a security in legal literature, it can be concluded that most of the legal theory is capable of uniting at least two characteristics characterizing a security. The first is the instrument representing a security and there is no dispute about the fact that most legal literature law is a key term for the security. Such a view is confirmed not only by a historic reflection but also in the future. However, Progressis based on a more general concept of the instrument as a physical substrate. As a rule, it is an instrument in the classical meaning of a word, that is to say, a letter of paper. ${ }^{31}$ However, the nature of the physical substrate itself is not essential, it can be any capable of becoming a vehicle of information. In further analysis of this issue, we are confronted with illustrative diversity, in the context of the existence of book entry securities. As a

\footnotetext{
${ }^{26}$ Korauš et al., Using, 1101-12.

${ }^{27}$ Chance and Brooks, An Introductin, 156.

${ }^{28}$ Kotásek et al., Pravo, 227.

${ }^{29}$ Dědič and Pauly, Cenne, 174.

${ }^{30}$ Bratislava Regional Court, Judgment No 31Zm 111/2000.

${ }^{31}$ Funta, Discounts, 60-64.
} 
result, some authors admit that the document is to be understood as a historical, but not unconditional, character of a security.

The second is then a close-fitting of the type of rights attached to this instrument, described as an incorporation. However, sometimes the second characteristic feature, which is the value of the instrument, is given instead of the term incorporation. It points out that the price cannot be understood in the general sense, but in the legal sense of the term, which means that the instrument makes the valuable legal consequences associated with it. As described by Eliáš et al. "consequently, a security is confined to an instrument the content of which is capable of giving rise to rights, whereas the concept of a security does not include instruments which are legally irrelevant, despite the fact that they may be of great value to the parties involved, such as family photographs. ${ }^{32}$ "Indeed, the ability to give rise to a right and a probate effect in the security is that certain rights and, where appropriate, obligations are attached to $\mathrm{it}^{33}$. However, it is wrong to interpret the law in accordance with which the right to give a written statement constituting a security is connected in such a way that it is necessary to exercise that right. Such a right of construction was typical for the period after the change of social constitution was found to be the result of the effect of the characteristics of the security in Article 185i of Act No. 99/1963 Col. The Code of Civil Procedure where the court has dealt with a document that has to be submitted for the application of the law. Thus, from that period, it was only the only sign that formed the concept of incorporation. It was a sign of the exercise of the right attached to a written declaration of intent representing a security.

\section{Security from the perspective of applicable law}

The term 'security' can be inferred not only from the law itself 'ex lege' but also from other legal provisions. This means that a source of knowledge may also be other legislation and, when crossing the boundaries of the continental law, even other legal sources, in particular judicial decisions. ${ }^{34}$

Not only legal theory but also legal practice in Czechoslovakia and then in Slovakia did not address the definition of a security and its legal basis for many decades. This was since the economic importance of the securities was marginal under the conditions of the centrally planned economy. According to the then theoreticians ${ }^{35}$, they were burgeous survival, which did not need to be dealt with in the field of legal science. Except for law on currency exchange and cheque ${ }^{36}$ did not exist.

\footnotetext{
${ }^{32}$ Eliáš et al. Nový, 45.

${ }^{33}$ Horvathova and Cajkova, Framework, 106-25.

${ }^{34}$ Vilcekova et al., Securization, 5061-69.

${ }^{35}$ Pokorna et al., Zrušeni, 894.

${ }^{36}$ Act No. 191/1950 Coll. the law on currency exchange and cheque.
} 
Until the entry into force of Act on securities, ${ }^{37}$ there was no legal definition of this term in our conditions. Indirectly, it was the first to define the Code of Civil Procedure, which states that 'it is possible to redeem a lost or lost list to be submitted for the application of the law.' However, such wording does not indicate that the instruments also have the status of securities. However, the Slovak Republic has not made any exception to this concept since most European countries have left the definition of this concept to legal theory and case law. According to Mittelman et al., "in English law it is also not the case that securities are the objects of legal relationships which are provided for by law, but the determination as to what a security is at stake is the judicial practice of which. ${ }^{38}$,"

Article 965 of the Swiss Law of 1911 defines a security as a document to which the law is attached in such a way that it cannot be transferred or transferred without the instrument. The definition of a security is also found in the judgment of the Supreme Court of 1940, Ref. Rc 17931 Rv I 529/40. In its view, 'securities are those instruments which are the substantive condition of the creation, transfer, execution or all the duration of the law of which they are issued; In so doing, they differ from those of accompanying (legitimation), which constitute evidence of the right, but they are not the holders of the right and the right to the law.'

A completely different and very broad interpretation of the concept of a security is found in the decisions of the US Supreme Court where, unlike a continental system of law, judicial precedents belong to a formal source of law. As is apparent from the statement of reasons for the US Supreme Court ruling in the Securities and Exchange Commission c/a, J. Howey Co is a security, any investment contract under which a person invests his money in a joint venture and is led by an expectation of profit solely on the basis of the efforts of the trader or a third party. ${ }^{39}$ It follows from the foregoing that, in contrast to Central European legal cultures, the concept of security in American law is not decisive for the application or transfer of a right, but rather the content of the legal relationship created by the securities. The substance of the security is, to this effect, an investment contract, whereas the notion of a security corresponds rather to our economic concept of an investment. However, it is important to draw attention to the fundamental difference in the development of legal cultures. Therefore, we consider any comparison of the Slovak and/or European concept of a valuable paper with its understanding in the Anglo-American system of the right to be highly problematic. ${ }^{40}$

In our terms of continental law, even in the light of what is customary, it is possible, subject to some simplification, to refer in a context only to a law or, as the case may be, to a maximum of legislation and, therefore, the legal definition of a security. This is true although, in today's information age perspective, a law as a source of knowledge of what constitutes a security appears to be very natural in legal circles. The first attempt to legally define a security is not yet published to the Slovak

${ }^{37}$ Act No. 600/1992 Coll. on securities.

${ }^{38}$ Mittelman et al., Securities, 182-87.

${ }^{39}$ Funta, The EU, 60-64.

${ }^{40}$ Pauly, Teoreticke, 26. 
legislator. Act No. 600/1992 Col. on securities did not give thought to create a legal definition of the security. It confined itself to a superficial solution consisting only of the enumeration of the types of security. Under Paragraph 1 of that law, shares, temporary letters, shares, bonds, coupons, notes, vouchers, bills, cheques, it is then usually concluded that there is a limited number of types of securities in our legal order, since only instruments which are to be registered as securities are to be regarded as securities. Such a legal structure, which was at least illustrative for the purposes of knowledge of the concept of a security, was, at the time when it was established, with a view to the then, at the time, a general level of security in the field of securities. As stated Stefko et al., "this was a very naïve practice that did not sufficiently address the problems of the then capital market. Nevertheless, it was used by the legislature." ${ }^{41}$

It has been amended for 12 times during its 10 -year period of validity. However, given the proposed scope of the amendments needed, it was adopted with effect from 1 January 2002 the Act under the new name - the Securities and Investment Services Act. The legal definition of the security in this legislation comes from $\S 2$. In its view, 'a security is an appreciable entry in a legally established form and form to which the rights under this Act are attached, and the rights under special laws, in particular the entitlement to claim certain property benefits or to exercise certain rights against legally designated persons.' This statutory definition then gives rise to three basic features of the security. First, the valuable paper is an appreciable entry. Importantly, the law is no longer strictly insisting that they be a document. The second legal feature of the security is the subjective right of its owner to require some financial or other, for example, a property transaction. ${ }^{42}$ The last, third character of the security shall be the condition of compliance with the legal form and the form of the security. The absence of any of these three conditions would have the effect of not being a security in the legal sense of the term. The strict nature of the Slovak legislation is more consistent with Paragraph 3, which exhaustively lists the various types of securities. This means that in order to be a security, the conditions of $\S 2$ and $\S 3$ of the Securities Act must be cumulatively fulfilled.

According to Pauly "Czech Act No 89/2012 Coll. The Civil Code has been in force since 2014 to abandon the Czechoslovak concept of 'security'. It has defined a security as a 'document to which the right is attached in such a way that, after a security has been issued, it cannot be exercised or transferred without that document. ${ }^{43}$ " Here appears at first sight that, after continuous years of preparation, the Czech legislature has failed to recognise that there is also a book-entry form of the security. As is apparent from the explanatory memorandum to the proposal for a Civil Code, it was based on Article 965 of the Swiss Law on obligating law, the concept of which is based on other legislation, in particular the Italian or Polish law.

\footnotetext{
${ }^{41}$ Stefko et al., Bankruptcy, 212.

${ }^{42}$ Borsekova et al., Sustainable, 8643.

${ }^{43}$ Pauly, Teoreticke, 26.
} 


\section{Discussion}

Although there is a large number of foreign economic literature in particular, the fact that we have already given an overview clearly shows that there are a number of doubts as to the definition and understanding of the concept of a valuable paper from an economic point of view. In Samuelson and Nordhaus, the question arises as to whether the securities may be referred to explicitly as mere monetary assets and limited to their legitimate role as an attestation of a law. On the spot, there are doubts as to whether this textbook does indeed describe the course of the securities, or even understand what the securities are, and what should be its very essence. The Mishkins definition is more acceptable but also far from perfection. We do not consider it right to focus on a security merely for a certain, very broad, right, because the concept of an asset does not cover everything that a security can bring to its owner.

Even a theoretical one - a legal definition of a security suffers from number of problems, in particular the existence of a number of legal schools, inconsistency of approach and, in particular, the diversity of legal cultures. If we were to focus on the majority view of the legal theory, according to which the security is a law, a prima facie opinion can be drawn at first sight. However, that does not stand up to a characteristic of the term of the security. In our view, it is unrealistic to imagine a document with which the right is closely linked without it being a document a certain right. This is because such a characteristic is already inherent in the very close connection between a right and a document, which means that, as a separate term, the security appears to be entirely superfluous.

In a critical view of the Slovak legislation, the specialist literature almost always points to a more sophisticated and appropriate wording of the Czech legislation, which is now understood by the Czech Civil Code. It is a private law code as a lex generalis. In more than three paragraphs, it seeks to unify the whole area of Czech private law, including both the rights of the securities and the term itself. In the present case, after only two years of effectiveness, it was the Czech theoretical and private sector, as well as legal practitioners, that the road such as that chosen by the Czech legislature was not correct. A return to more than one hundred years of the old definition of a 'security' is only a matter of opacity and chaos.

\section{Conclusion}

The economic definition of a security meets a number of problems. The first is that a considerable part of the economic literature fully ignores this concept and only a minor part of it works. Nevertheless, the definitions to which economists are only very marginal and certainly cannot be the basis for a serious definition of that concept. However, it is necessary to recognise, at the very least, some economists as to how to deal with that concept. However, they are based, in particular, on the theory of the law, which leads them, in general, to expect from them. The illustrative fragmentation of economic theory on fundamental concepts which are likely to be 
related to its borderless nature is also problematic. This means that it is in no way possible to meet the economic definition of a security.

Although economic theory cannot provide us with a reliable response to what is a security at all, the theory of the law also has considerable problems, the basis of which can also be seen in the case of the lack of uniformity of legal theory. Nevertheless, at least as part of the definition of the constituent elements of the individual characters of the security, there is some consensus which cannot be fully met. The plurality of opinions, as a fundamental human right, also has a significant negative impact on securities. It creates "misconceptions" about what the security is. The biggest myth is that a security must be one of its underlying concepts. We have conclude that a theoretical legal picture of the concept of a security is not entirely clear and will require further examination. In addition to such a procedure, the legislation itself leads us to provide us with the legal and therefore universally binding term of a security.

We cannot be complacent about the definition of a security, nor on how to provide it with theory of law, let alone economic theory. However, in general, neither our expectations nor hopes have been honored from the legal definition of this term. We see a fundamental problem in several legal systems, but in the fundamental diversity of the various legal systems. Several European States' legal systems to define a valuable paper are based on general legal literature, which has historically been overcome. Rather than a realistic definition of this concept, other legal systems merely enumerate the individual securities, bringing them to the level of economic theory. We found that the most appropriate legislation was Slovak. Its mandatory nature and the cumulative fulfilment of the features contained in Sections 2 and 3 of the Securities and Investment Services Act does not, unlike most of the legal orders, provide room for unjustified speculation on whether or not it is a security. On the basis of our finding, we are of the opinion that, in the context of the 'de lege ferenda', the Slovak legislation could form the basis for a new definition of the concept of a security in a number of legal systems.

\section{Acknowledgement}

This article is an output of the science project VEGA 1/0813/19 "Managing the development of innovative and start-up forms of businesses in international environment and verification of INMARK concept."

\section{Bibliography}

1. Bannock Graham and Baxter Ronald. ,The Penguin Dictionary of Economics “ London: Penguin Books, 1992.

2. Bartosek Milan. „Encyklopedie rimskeho prava [Encyclopedia of Roman law].“ Praha: Academia, 2014.

3. Blackwell W. David, Griffiths Mark D. and Winters Drew B. „Modern Financial Markets: Prices, Yields, and Risk Analysis "London: Wiley and Sons Lmtd. Publishing House, 2007. 
4. Bohdalova Maria and Gregus Michal. „Stochastické analýzy finančných trhov [Stochastic analysis of financial markets]. " Bratislava: Comenius University in Bratislava, 2012.

5. Borsekova Kamila, Klatik Jaroslav, Korony Samuel Kristofik Peter, Mihok Peter and Orvisky, Martin. „Sustainable Policy Measures Based on Implementation of Digital Technologies in Corrections: Exploratory Study from Slovakia and Beyond“ Sustainability 12, no. 20, Article no: 8643 (2020), doi: 10.3390/su12208643.

6. Bratislava Regional Court. Judgment No 31Zm 111/2000.

7. Dedic Jan and Pauly Jan. „Cenné papiry [Securities].“ Praha: Prospektrum, 1994.

8. Elias Karel et al. „Nový občansky zakonnik s aktualizovanou duvodovou spravou [New Civil Code with updated explanatory memorandum]. “ Praha: Sagit, 2014.

9. Englis Karel. „Narodni hospodarství [National economy]. “ Praha: Orbis, 1946.

10. Federal Assembly of the Czech and Slovak Federal Republic. „Act No. 600/1992 Coll. on securities" accessed January 1, 2021. https://www.slov-lex.sk/pravnepredpisy/SK/ZZ/1992/600/20020101

11. Fuchs Karel and Tuleja Pavel. „Zaklady ekonomie [Basics of economics]. “ Praha: Ekopress, 2015.

12. Funta Rastislav. "Discounts and their effects - economic and legal approach." Danube 5, no. 4 (2014): 277-85.

13. Funta Rastislav. ,, The EU Decline? Future Prospect Through Investment Strategy“. 13th Iinternational Scientific Conference on Iinternational Relations 2012: Contemporary Issues of World Economics and Politics, 60-64, 2012.

14. Gernat Peter, Kostalova Zuzana and Lyocsa Stefan." What drives U.S. financial sector volatility? A Bayesian model averaging perspective." Reserch in international Business and Finance 51, Article Nr: 101095, 2020 , https:/www.sciencedirect.com/science/article/abs/pii/S0275531919302697.

15. Horvathova Zuzana and Cajkova Andrea. "Framework of the Sickness Insurance in the Czech Republic and Selected Countries of the European Union." European Journal of Transformation Studies 7, no. 1 (2019): 106-25.

16. Chance M. Don and Brooks Robert. „An Introduction to Derivatives and Risk Management." London: Irwin Publishing, 2007.

17. Chovancova Bozena, Dorocakova Michaela and Linnertova Dagmar. „Two investment options for bearish etf investors: Inverse etf and shorting etf,“ International Journal of Financial Studies 7, no. 2 (2019), https://www.mdpi.com/2227-7072/7/2/31.

18. Korauš Antonin, Gombar Miroslav, Kelemen Pavel and Backa Stanislav. "Using quantitative methods to identify insecurity due to unusual business operations," Entrepreneurship and Sustainability Issues 6, no. 3 (2019): 1101-1112, https://jssidoi.org/jesi/article/272.

19. Kotasek Josef, Pihera Vlastimil, Pokorná Jarmila and Jindrich Vitek. „Právo cenných papiru [Securities law]. "Praha: C. H. BECK, 20142.

20. Lalik Tomas. "Slovak Constitutional Court: Tax and Delegated Legislation from a Constitutional Perspective Judgment of 22 January 2014, PL US 5/2012." Icl JournalVienna Journal on Iinternational Constitutional Law 8, no. 4 (2014): 467-73.

21. Lyocsa Stefan and Todorova Neda. „Trading and non-trading period realized market volatility: Does it matter for forecasting the volatility of US stocks?" International Journal of Forecasting 36, no. 2 (2020): 628-45. https://www.sciencedirect. com/science/article/abs/pii/S0169207019302250.

22. Macíková Lucia, Smorada Marian, Dorcak Peter, Beug Benjamin and Markovic Peter. „Financial aspects of sustainability: An evidence from Slovak companies,“ 
Sustainability 10, no. 7, Article no. 2274, (2018), https://www.mdpi.com/20711050/10/7/2274.

23. Mierop Van der Marc. „Dejiny starovekeho blizkeho vychodu [History of the ancient Middle East]. " Praha: Academia, 2010.

24. Mishkin Frederic. „The Economics of Money, Banking and Fnancial Markets.“ Columbia: Harper Collins Publisher, 2013.

25. Mittelman Alexandra, Mucha Boris and Peracek Tomas. "Securities and its theoretic legal formulation not only in the conditions of the Slovak republic." $19^{\text {th }}$ International scientific conference on economic and social development, (2017): 182-87.

26. Mucha Boris. "Vykon vladneho auditu medzinarodnych zdrojov [Performance of government audit of international sources]." Bratislava: Comenius University in Bratislava, 2020.

27. Mucha Boris. "Tools to increase the effectiveness of comprehensive management of emergencies affected by climate change in the Slovak republic" 19th International Multidisciplinary Scientific Geoconference, SGEM, (2019):573-80.

28. Mura Ladislav, Buleca Jan, Hajduova Zuzana and Andrejkovic Marek. „Quantitative Financial Analysis of Small and Medium Food Enterprises in a Developing Country“. Transformation in Business \& Economics 14, no. 1 (2015):212-24, http://www.transformations.knf.vu.lt/34/article/quan.

29. Mura Ladislav, Gontkovicova Barbora, Dulova Spisakova Emilia and Hajduova Zuzana. "Position of Employee Benefits in Remuneration Structure." Transformations in Business \& Economics 18, no. 2 (2019): 156-73.

30. National Assembly of the Czechoslovak Republic. Act No. 191/1950 Coll. on currency exchange and cheque" accessed January 1, 2021. https://www.slov-lex.sk/pravnepredpisy/SK/ZZ/1950/191/20151223.

31. National Assembly of the Czechoslovak Socialist Republic. Act No. 99/1963 Coll. The Code of Civil Procedure as amended." accessed January 1, 2021. https://www.slovlex.sk/pravne-predpisy/SK/ZZ/1963/99/20160614.

32. National Council of the Slovak Republic. Act. No. 566/2001 Coll. on Securities and Investment Services and on Amendments to Certain Acts (Securities Act), accessed January 1, 2021. https://www.slov-lex.sk/pravne-predpisy/SK/ZZ/2001/566/20200903.

33. Parliament of the Czech Republic. Act. Act No 89/2012 Coll. The Civil Code, accessed January 1, 2021. https://www.zakonyprolidi.cz/cs/2012-89.

34. Pauly Josef. „Teoreticke a legislativni zaklady cennych papiru [Theoretical and legislative bases of securities] “. Praha: Wolters Kluwer, 2016.

35. Pennant - Rea Rupert and Emmont Bill. „The Pocket Economist“, London: Backwell and the Economist Publications, 2010.

36. Pokorna Jarmila, Fucik Ivan, Janovec Michal, Pesicova Jitka and Tomaskova Eva. „Zrušení a zánik obchodní korporace s likvidaci [Liquidation of liquidated business corporations]. "Praha: Wolters Kluwer, 2020.

37. Randa Alois. "O cenných papírech, obzvlášte o skripturnich obligacich [About securities, especially scripting bonds]." Pravnik 1, 1889.

38. Samuelson Paul and Nordhaus William. „, The Economist“, Praha: NS Svoboda, 2013.

39. Simonova Jana, Centes Jozef and Beles Andrej. „Financial Analysis of Innovative Forms of Money.“ Entrepreneurship and Sustainability Issues 7, no. 1 (2019) 69-80, https://jssidoi.org/jesi/article/354.

40. Slahor Ludomir. "VAT evasion: Recent evidence from Slovakia." $26^{\text {th }}$ International Business Information Management Association Conference, (2015):1555-60. 
41. Srebalova Maria, Horvath Matej, Vacok Juraj, Vojtech Frantisek and Smutny Filip. "Legal obstacles to freedom to conduct a business: experience of the Slovak Republic," Entrepreneurship and Sustainability Issues 7, no. 4 (2020): 3385-3394, https://jssidoi.org/jesi/article/592.

42. Stefko Robert, Horvathova Jarmila and Mokrisova Martina. „Bankruptcy Prediction with the Use of Data Envelopment Analysis: An Empirical Study of Slovak Businesses." Journal of Risk and Financial Management 13, no. 9, Article no. 212 (2020), doi:10.3390/jrfm13090212.

43. Supreme Court of the Czechoslovak Republic. Case law of the Supreme Court of the Republic of 1940, No. Ref. Rc 17931 Rv I 529/40.

44. Supreme Court of USA. Case Law Securities and Exchange Commission c/a, J. Howey Co.

45. Svarc Martin. „Velka ekonomicka encyklopedia [Great Economic Encyclopedia]“. Praha: Linde, 2012.

46. Vilcekova Lucia, Kocisova Lucia, Mucha Boris and Peracek Tomas. „, Securitization of Liabilities in Slovak Business law" $31^{\text {st }}$ International Business Information Management Association Conference, (2018): 5061-69. 